\title{
Step by step onto the policy agenda
}

\author{
Dieser Artikel gibt einen Überblick über die \\ Entstehung der ökosozialen Gesamtrechnung \\ sowie alternative Indikatoren zur wirtschaft- \\ lichen Entwicklung. Gleichzeitig werden die \\ jüngsten Fortschritte beschrieben und prakti- \\ sche Anwendungen aufgezeigt. \\ Von Alistair Hunt
}

$\mathrm{T}$ he Standard National Accounts (SNA) framework originated with work done during the Second World War. The basic form of the national accounts as developed by Stone (1951) can be summarised as:

$$
\begin{aligned}
& \text { NNP }=\mathbf{C}+\mathbf{I}-\mathbf{D}+\mathbf{X}-\mathbf{M} \\
& \text { Where: } \\
& \text { NNP }=\text { Net National Product } \\
& \mathrm{C} \quad=\text { Consumption } \\
& \mathrm{I} \quad=\text { Investment } \\
& \mathrm{D} \quad=\text { Depreciation } \\
& \mathrm{X} \quad=\text { Exports } \\
& \mathrm{M} \quad=\text { Imports }
\end{aligned}
$$

Thus, the net national product (NNP) of an open economy consists of Consumption plus net investment (Investment minus Depreciation) plus net exports (Exports minus Imports). In the last 50 years the resulting indices, Net National Product, and particularly Gross National Product (GNP), have come to be regarded not simply as tools for economic management but also as indicators of economic performance and economic wellbeing, and of a country's "income". GNP measures economic activity in terms of the amount of final demand satisfied by economic output. The use of this figure as a measure of wellbeing rests on the assumption that wellbeing is proportionate to consumption of produced goods.

\section{External effects}

However, economic activity has many negative external effects. These can often be described as environmental externalities, a major example being the pollution to air, water, and soil caused by production. Some of the damage caused by this pol- lution is reflected in reduced output, as in the case of reduced agricultural output due to polluted soils and water supplies.

This damage is thus reflected in the national accounts, since output figures are lower than they would otherwise have been. Similarly, environmental damage directly affects human welfare and this loss is not reflected in the national accounts. Examples of this loss of welfare are the discomfort of breathing polluted air. An additional measurement problem associated with pollution stems from the fact that some resources are devoted to mitigating its consequences. This defensive expenditure does not contribute to welfare, but because it is final expenditure, it is counted as part of GNP. Finally, while estimates are made of the depreciation of manmade capital stocks, depreciation of natural capital stocks is not accounted for. Therefore, if a country depletes, for example, its forest stocks, its income is inflated by the proceeds, but there is no corresponding deduction to reflect the decrease in value of its asset. As a consequence of these problems Ahmad, El Serafy and Lutz (1989) point out that standard measures of national income provide neither an accurate reflection of citizens' welfare, nor an accurate indicator of the long-term prospects of the economy.

The neoclassical framework of Green National Accounting has been developed to deal in particular with two of the problems mentioned in the previous section. Firstly, the fact that the environmental damage caused by production and consumption has a negative effect on human wellbeing, and secondly that under the current SNA, the depletion of natural resource stocks is not counted as depreciation in calculating Net National Product.

\section{Developments of Green National Accounting theory}

A major issue in the development of Green National Accounts has been the identification of factors that should be corrected for in adjusting NNP. These include environmental services, environmental damages, defensive expenditures and resource depletion and are discussed under their respective headings.

Environmental Services: It has been suggested that the value of environmental services should be included in GNP. Hamilton (1994) notes that environmental services to production are already reflected in GNP since their contribution constitutes part of the value of production. However, as noted above, the direct contribution of environmental services to human welfare is not reflected in produced output. Thus, the suggestion $\rightarrow$ 


\section{„Sustainable economic welfare has risen much more slowly than GDP, and may even have fallen since 1980."}

that the value of these services should be included in GNP reflects the desire that GNP should be a measure of total welfare generated in the current period, including the welfare generated by environmental assets.

Environmental Damages: Peskin also suggested that environmental damages should be deducted from GNP, in order that net welfare derived from the economy and the environment should be accurately measured (1989).

Defensive Expenditures: Daly, for instance, suggests that defensive expenditures should be deducted from NNP since they constitute not a net contribution to welfare but the avoidance of a decrease in welfare (1989). However, Harrison (1989) and Vanoli (1995) argue against this. Harrison argues that such a deduction contravenes standard accounting practice, and that accounting cannot discriminate between items that clearly qualify as final expenditure in not being subject to further sale. Vanoli points out that it is moreover extremely difficult to identify those expenditures that are truly defensive.

Resource Depletion:The value of overall productive capital is reduced when stocks of productive natural capital, such as forests and fish stocks are depleted. The fact that standard national accounts do not reflect this is the major complaint of Repetto et al. (1989). The decrease in value of the asset is measured by the "resource rents" on the decrease in the resource stock, which is equal to the level of extraction in the case of non-renewable resources.

Resource rents refer to the profits that accrue to a resourceextracting firm due to the fact that part of the price of the resource can be considered to be compensation for the fact that a valuable asset (i.e. the resource stock) is being liquidated. Thus, resource rents accrue where a non-renewable resource is being exploited, and where a renewable resource is exploited unsustainably. Resource rents are also known as Hotelling rents.

This amount should be deducted in the calculation of NNP as representing part of the depreciation of the overall capital stock. In a practical application of this adjustment, Repetto et al. showed for the case of Indonesia that while GDP grew by 7.1 per cent between 1972 and 1984, accounting for the loss of forestry, oil and soils meant that their estimate of environmentally adjusted NDP grew by only four per cent in that period.

\section{Green National Accounting in practice}

The first version of the UN System for Economic and Environmental Accounting (SEEA) was published in 1993. It is closely linked to the structure of the SNA, and rather than reflecting environmental issues in the core accounts, includes them in satellite accounts which can be used to adjust the final figures. As El Serafy (1996) noted: "The objective has been to reflect environmental deterioration in the SNA to the extent that the SNA framework will allow." The SEEA accounts can be thought of as being in three sections, as follows:

1 Physical Flow accounts - supply and use tables.

I Economic data - juxtaposing the physical environmental accounts with monetary accounts. This reflects how income is distributed and redistributed, and includes environmental protection expenditure and the value of natural resource stocks (asset accounts).

- Valuing degradation - Extension of the framework to cover interactions not presently valued, in particular the causes and impacts of environmental degradation.

In the following, we focus on developments in the third section, where most research effort has been made. Valuing degradation: Two broad methods have been used to value degradation: cost-based methods and damage-based methods.

Cost-based methods account for how much would it cost to avoid the generation of residuals by changing production and consumption patterns. Within this type of method, there are two main approaches:

- To estimate the value of NDP if hypothetical environmental standards are met using current technologies and costs.

- To engage in "greened economy modelling" in order to model the effects of following the least-cost approach to reach certain environmental standards on economic activity and output.

The EC-funded GREENSTAMP project methodology is based on a requirement for strong environmental sustainability. According to this approach, the appropriate way in which to express society's "demand" for environmental goods is by respecting environmental standards compatible with preserving the ecological base required for sustainability (GREENSTAMP Project 1997). The methodology estimates sustainable national income, using an empirically calibrated multi-sector equilibrium model of a national economy to estimate economic output that is consistent with respecting environmental sustainability standards. It therefore provides policymakers with information on the costs to be borne by society in meeting given standards of environmental protection. The major disadvantage with this approach is that the complexity of a real national economy is so great that the inaccuracies associated with attempting to model an economy are at least as great as those associated with the damage-based method.

Damage-based methods account for what is the value of the 
damage caused by current levels of residual generation. The ECfunded GARP project is an example of an empirical study that gathers the type of information that could be used to estimate a Green NNP, or could be provided as satellite accounts to be interpreted alongside standard national accounts. The aim of the GARP welfare-based approach is to develop a practically measurable estimate of the net welfare that an economy generates. The core objective was therefore to provide a scientifically robust method for the calculation of damages to human health, crops and materials. Thus, information is delivered to policy makers in the form of both physical and monetary impact estimates. Problems with this approach include the fact that this type of income in general does not measure sustainability even in theory, and that observable prices in any case would not allow us to do so.

It is unlikely to be feasible to provide a single indicator that measures both current welfare and long-term sustainability. Whilst the GARP methodology attempts to address the first, an example of the latter, separate from indicators of wellbeing, is the Genuine Saving framework, discussed below.

\section{Genuine Saving}

Genuine Saving is a methodology that concentrates on the measurement of total wealth as a sustainability indicator, (Hamilton and Clemens 1999) and builds on original work done by Pearce and Atkinson (1993). Genuine saving is defined as investment in produced assets and human capital (i.e. equal to conventional savings) less the value of depletion of natural resources and the value of accumulation of pollutants. Thus, it is in effect the value of the changes in the economy's overall capital stocks. Negative genuine saving is shown by Hamilton and Clemens to correspond to unsustainability, given the assumptions of their model.

The results of calculations of genuine saving performed by the World Bank are calculated for the period 1970-1994 and show that accounting for resource depletion in this way does affect the indicators of sustainability based on national accounting data, since several countries have positive net savings, but negative Genuine Savings. Genuine Savings rates are particularly low, and often negative, for Sub-Saharan Africa and for the Middle East and North Africa. One of the major criticisms of Genuine Saving (e.g. Martinez-Alier 1995) is that it provides an indicator of only Weak Sustainability, assuming as it does that investment in produced capital can compensate for decreases in the value of natural resources.

\section{Alternative indicators of wellbeing}

The experiences reported above imply that it may be necessary to construct separate indicators for current wellbeing and long-term sustainability. An alternative framework, the Index of Sustainable Economic Welfare (ISEW), first proposed by Daly and Cobb (1989), attempts, to measure current wellbeing, ad- justed to account for issues relating to sustainability. They argue that current welfare should be measured as the current flow of services from all sources, rather than current output of marketed goods. They estimate this flow for the USA for 1990, by adjusting consumption as designated in table 1 :

Table 1: Flow of services for the USA in 1990

\begin{tabular}{|c|c|c|}
\hline ISEW & $=$ Personal consumption ad justed for income inequality & 1164 \\
\hline (a) & + Services of household labour & 520 \\
\hline \multirow{3}{*}{ (b) } & + Services of consumer durables & 225 \\
\hline & + Services of highways and streets & 18 \\
\hline & +Consumption portion of public spending on health and education & 45 \\
\hline (c) & - Spending on consumer durables & 235 \\
\hline \multirow[t]{4}{*}{ (d) } & - Defen sive private spending on health and education & 63 \\
\hline & - Costs of commuting and auto accidents & 67 \\
\hline & - Costs of personal pollution control & 5 \\
\hline & - Cost of air, water and noise pollution & 39 \\
\hline$\overline{(e)}$ & - Loss of wetlands and farmland & 58 \\
\hline (f) & - Depletion of non-renewable resources & 313 \\
\hline \multirow[t]{4}{*}{ (h) } & $\begin{array}{l}\text { - Long-term damage from nuclear wastes, greenhouse gases, ozone } \\
\text { depletion }\end{array}$ & 371 \\
\hline & + Net capital growth & 29 \\
\hline & \pm Change in net international investment position & \\
\hline & & $=\$ 818$ \\
\hline
\end{tabular}

Source: Daly/ Cobb 1989

Daly and Cobb's initial estimates for the USA have been followed up by an application for the USA by Cobb and Cobb (1994) and estimates for Germany (Diefenbacher 1994), Sweden and the UK (Jackson et al. 1997). Updates to the methodology have been made by Jackson et al. (1997) in their application to Austria. The conclusion for all these studies is that sustainable economic welfare has risen much more slowly than GNP, and may even have fallen since 1980.

However, critics such as Neumayer (1998) maintain that one cannot measure current economic welfare using factors that pertain to future wellbeing and sustainability, and likewise an indicator of sustainability should not include factors pertaining to current welfare. Therefore, he maintains that one needs at least two indicators to measure these two distinct issues. Furthermore, the reduction of the issue of sustainability to a single indicator seems to imply substitutability in consumption and production, an assumption that the advocates of strong sustainability would usually dispute.

The GREENSENSE project therefore attempted to develop a framework for economic-environmental accounting that addresses the criticisms that have been made of the existing frameworks, while capitalising on their strengths. The framework developed is known as the Index of Consumption Corrected for Environmental Damage (ICCED). The major objectives of the reporting framework are to reflect:

1 How increases in wellbeing are reduced when (certain categories of) environmental impacts are accounted for.

- How far current levels of environmental impacts are from (some definition of) sustainable impacts, and what dynamic policy targets could bring environmental impacts down to sustainable levels.

- The net effect on projected (short-term) futurwellbeing of implementing the policies identified in the previous objective. $\rightarrow$ 
The categories addressed in the project were Air Pollution, Climate Change, Biodiversity Loss, Natural Resource Depletion, Toxic Substances, Urban Environmental Problems (specifically noise), Waste and Water Pollution. These constitute eight of the ten main categories of the EUROSTAT pressure indices; the ninth 'Marine Environment \& Coastal Zones' is excluded here, as the focus is on land area of the EU, and the tenth 'Ozone Layer Depletion', were excluded as this problem must be (and is being) addressed at the global level.

The two sets of information - on environmental damage costs and costs of meeting sustainability targets - are combined in a country's ICCED table on a per-capita basis. The ICCED table for Germany is presented in table 2 .

The first and second columns in the table show consumption corrected for environmental damage for the years 1990 and 1998. The third and fourth columns show consumption corrected for environmental damage for projected economic growth and environmental damage, under two separate environmental policy assumptions. These are intermediate sustainability, that is meeting the standards envisaged in current EU legislation, and strong sustainability, that is of putting the economic-environmental system onto a path that involves bringing the damage and depletion of the environment to within the assimilative and regenerative capacity of the environment before damage is done to critical natural capital.

Table 2: The ICCED for Germany

\begin{tabular}{|c|c|c|c|c|}
\hline & $\begin{array}{l}\text { Billions of (2000) } \\
\text { Euros }\end{array}$ & & Intermediate & Strong \\
\hline & 1990 & 1998 & $\begin{array}{r}\text { Target } \\
2006\end{array}$ & $\begin{array}{r}\text { Target } \\
2006\end{array}$ \\
\hline $\begin{array}{l}\text { GDP } \\
\text { Fintion }\end{array}$ & 17025 & 23791 & 28198 & 28198 \\
\hline Expenditure & 13030 & 18258 & 22132 & 22132 \\
\hline $\begin{array}{l}\text { Env. Damage } \\
\text { Env Damage as \% }\end{array}$ & 863 & 456 & 290 & 277 \\
\hline Consumption & 6.62 & 2.50 & 1.31 & 1.25 \\
\hline Env Damage as $\%$ GDP & 5.07 & 1.92 & 1.03 & 0.98 \\
\hline Avoidance cost & & & 0.22 & 0.24 \\
\hline ICCED & & & 21841 & 21854 \\
\hline
\end{tabular}

\section{Conclusions}

The conventional GNP national accounting measure does not include negative effects on welfare from environmental pollution, nor does it give any indication as to whether the country's economic activity fulfils any criteria of environmental sustainability, however defined. Various recent research efforts have attempted to address these concerns and develop more comprehensive measures of welfare and sustainability - the EC GREENSENSE project being the most recent. The UNSEEA work also continues intermittently to consider how these measures should best be used with the conventional SNA framework that measures GNP. At present it is perhaps fair to say that the lack of environmental data availability somewhat limits the empirical results for policy purposes at present, though the magnitude of the estimates made in the various research initiatives indicate that welfare and sustainability issues associated with the environment should remain high on the policy agenda.

\section{Literatur}

Ahmad, Y.J./ El Serafy, S./ Lutz, E. (Eds.): Environmental Accounting for Sustainable Development. The World Bank, Wahsington 1989.

Cobb, C./ Cobb, J. (Eds.): The Green National Product. Lanham1994.

Daly, H.E.: Toward a Measure of Sustainable Social Net National Product. In: Ahmad et al. (1989).

Daly, H.E. /Cobb, J.B.: For the Common Good: Redirecting the Economy Towards Community, the Environment and a Sustainable Future. London 1989.

Diefenbacher, $\mathrm{H}$. : The index of sustainable economic welfare: a case study of the Federal Republic of Germany. In: Cobb, C.S./ Cobb, J.B. (Eds.): The Green National Product: A Proposed Index of Sustainable Economic Welfare. Lanham 1994. P. 215-245.

El Serafy, S.: Environmental Accounting for Sustainable Development: Conceptual and theoretical Issues Relating to the System of Integrated Environmental and Economic Accounting (SEEA). In: Journal of Economic Cooperation among Islamic Countries, 17, 1-2, 1996. P. 87-107.

GREENSTAMP Project (Ed.): Methodological Problems in the Calculation of Environmentally Adjusted National Income Figures. Final Report to the European commission DGXII. 1997.

Hamilton, K.: Green Adjustments to GDP. In: Resources Policy 20,3, 1994.

Hamilton, K./ Clemens, M.: Genuine Savings Rates in Developing Countries. In: The World Bank Economic Review, 13,2, 1999. P. 333-356.

Harrison, A.: Introducing Natural Capital into the SNA. In: Ahmad et al. (1989).

Jackson, T. et al.: An Index of Sustainable Economic Welfare for the UK 19501996. University of Surrey Centre for Environmental Strategy. Guilford 1997.

Martinez-Alier, $\mathrm{H}$ : The environment as a luxury good or "too poor to be green"? In: Ecological Economics 13,1, 1995. P.1-10.

Neumayer, E.: The ISEW: Not an index of sustainable economic welfare. In: Social Indic. Res. 48, 1998. P. 77-101.

Pearce, D.W./ Atkinson, G.: Capital Theory and the Measurement of Sustainable Development: An Indicator of Weak Sustainability. In: Ecological Economics 8, 1993. P.103-8.

Repetto, R./ Macgrath, W./ Wells, M./ Beer, C./ Rossini, F.: Wasting Assets: Natural Resources in the National Income Accounts. World Resources Institute. Washington D.C. 1989.

Stone, R.T.: Functions and Criteria in a System of Social Accounts. Income and Wealth Series I. Cambridge 1951.

Vanoli, K: Reflections on Environmental Accounting Issues. In: Journal of the International Association for Research in Income and Wealth, Series 41, 1995

\section{AUTOR + KONTAKT}

Alistair Hunt ist Wissenschaftlicher Mitarbeiter und Dozent an der University of Bath.

University of Bath, Department of Economics \& International Development, Bath BA2 7AY, UK. Tel. 0044/(0)1225/3832-44,

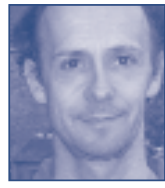

E-Mail: A.S.P.Hunt@bath.ac.uk 
(c) 20I0 Authors; licensee IÖW and oekom verlag. This is an article distributed under the terms of the Creative Commons Attribution Non-Commercial No Derivates License (http://creativecommons.org/licenses/by-nc-nd/3.o/), which permits unrestricted use, distribution, and reproduction in any medium, provided the original work is properly cited. 